\title{
MODELING OF SURFACE GEOMETRIC STRUCTURE STATE AFTER INTEGRATEDFORMED MILLING AND FINISH BURNISHING
}

\author{
Stefan BERCZYŃSKI, Daniel GROCHAtA \\ West Pomeranian University of Technology \\ Zenon GRZĄDZIEL \\ Maritime University of Szczecin
}

\begin{abstract}
:
The article deals with computer-based modeling of burnishing a surface previously milled with a spherical cutter. This method of milling leaves traces, mainly asperities caused by the cutting crossfeed and cutter diameter. The burnishing process - surface plastic treatment - is accompanied by phenomena that take place right in the burnishing ball-milled surface contact zone. The authors present the method for preparing a finite element model and the methodology of tests for the assessment of height parameters of a surface geometrical structure (SGS). In the physical model the workpieces had a cuboidal shape and these dimensions: (width $\times$ height $\times$ length) $2 \times 1 \times 4.5 \mathrm{~mm}$. As in the process of burnishing a cuboidal workpiece is affected by plastic deformations, the nonlinearities of the milled item were taken into account. The physical model of the process assumed that the burnishing ball would be rolled perpendicularly to milling cutter linear traces. The model tests included the application of three different burnishing forces: $250 \mathrm{~N}, 500 \mathrm{~N}$ and 1000 $\mathrm{N}$. The process modeling featured the contact and pressing of a ball into the workpiece surface till the desired force was attained, then the burnishing ball was rolled along the surface section of $2 \mathrm{~mm}$, and the burnishing force was gradually reduced till the ball left the contact zone. While rolling, the burnishing ball turned by a $23^{\circ}$ angle. The cumulative diagrams depict plastic deformations of the modeled surfaces after milling and burnishing with defined force values. The roughness of idealized milled surface was calculated for the physical model under consideration, i.e. in an elementary section between profile peaks spaced at intervals of crossfeed passes, where the milling feed $f_{w m}=0.5 \mathrm{~mm}$. Also, asperities after burnishing were calculated for the same section. The differences of the obtained values fall below $20 \%$ of mean values recorded during empirical experiments. The adopted simplification in after-milling SGS modeling enables substantial acceleration of the computing process. There is a visible reduction of the Ra parameter value for milled and burnished surfaces as the burnishing force rises. The tests determined an optimal burnishing force at a level of $500 \mathrm{~N}$ (lowest $\mathrm{Ra}=0.24 \mu \mathrm{m}$ ). Further increase in the value of burnishing force turned out not to affect the surface roughness, which is consistent with the results obtained from experimental studies.
\end{abstract}

Key words: Surface geometric structure, milling, burnishing, hybrid machining, FEM modeling

\section{INTRODUCTION}

Technology of machine component manufacturing in recent years has become increasingly integrated, often combining various manufacturing technique in one operation. Previously the most commonly combined were formed machine cutting of elements and abrasive methods of product surface finishing. However, technological concentration in scientific descriptions and in industry more and more frequently refers to various cuts performed at a single machining centre $[5,6,7,8,11]$. In case of diversified shape products with spatially complex surfaces (moulds and dies) it is common to combine rough and formed milling with finish burnishing of surfaces $[1,2,3,4,5,6,7,8,9$, $10,11,13]$. Single products, such as injection moulds for plastics or car body sheet dies have to have an appropriate state of surface geometric structure (SGS), achieved in the final machined cut $[1,2,5,6,7,8,9,10,11]$. Requirements that the process engineer faces are hard to be satisfied. The ultimate state of SGS, its texture and height of asperities, depends on the type and kind of tools used and values of technological parameters $[1,2,5,6,7,8,9,10]$, as well as characteristics of the machined material.

Modeling of integrated machining operation allows determining optimal kinematic-geometric relations of cuts combined into one operation. For predefined values of technological machining parameters we can assess how their interaction affects the final SGS state. Residual stresses that are hard to measure can also be determined [2].

The most important aspect, however, in manufacturing single parts is the choice of such values of machining parameters that will ensure specific requirements of the customer. In the process of making expensive and complex tools, such as casting moulds and dies one cannot afford practical seeking by trial and error method to choose an acceptable set of machining parameters. These authors present a method of preparing a FEM model and research methodology for the assessment of values of SGS height parameters. The results of model-based tests were verified by comparing them to the results of an empirical experiment, taking into account two height parameters: $R_{a}$ and $R_{q}$. 


\section{SURFACE MILLING AND BURNISHING}

Formed milling of complex spatial surfaces generally makes use of spherical and torus cutters. Both leave traces, mainly asperities resulting from cutting crossfeed and the diameter of the cutting plate. The roughness due to feed per revolution is in most cases negligibly small. As a rule, in such cases milling is followed by burnishing applied perpendicularly to the direction of crossfeed cutting (Figure 1). Burnishing, i.e. plastic machining of the surface, is accompanied by some phenomena occurring directly in the contact zone of the burnishing tool (Figure 1) [12]. Due to a force applied by a hard tool with a radius $\mathrm{R}$ to the rough surface of the workpiece, high peaks of the surface are lowered. Once the peaks are plasticized, they get filled with small volumes of material of the valleys locally adjacent to the peak. The burnishing effect mainly depends on material hardness $\mathrm{H}$ and its roughness $\mathrm{R}_{\mathrm{ain}}$ formed by a cut preceding burnishing $[2,6,7,8,11,12]$. Of basic burnishing technological parameters, including burnishing force $F_{b}$, feed $f_{b}$ and the number of passes $n_{p}$ of the burnishing tool, burnishing speed $v_{b}$ has the least impact on SGS $[2,11]$. Depending on the hardness of material being burnished, one of two methods is used. For soft and plastic materials slide burnishing is the most frequent method $[1,9,10]$, in which the coefficient of friction $\mu$ between the tip of the burnishing tool and rough surface of the workpiece is a decisive component for the final effect.

During the burnishing of high hardness objects the friction forces $\mathrm{F}_{\mathrm{fr}}$ are minimized by using the pressing-roller burnishing, which additionally increases tool life $[2,3,5,6$,
$7,8,11]$. The kinematics of the burnishing process and technological parameters affect local load $N_{c}$ of the surface $[2,6,7,8]$ within the workpiece-tool contact area. Besides the final roughness $R_{a b}$, the process engineer takes into consideration the following output variables of hybrid machining of surface: changes in the ratio of surface hardness to stresses in the surface layer $\mathrm{H}_{i t} / \mathrm{E}_{i t}[2,12]$, increase in surface hardness $\mathrm{HV}$, residual stresses $\sigma_{\mathrm{a}}$ [2], and a number of changes in metallographic structure of steel. A certain range of optimal values of technological parameters can be identified for burnishing; above this range there is no significant improvement of SGS state $[2,6,7,8]$.

\section{PHYSICAL MODEL OF MILLING AND BURNISHING}

Tests of milling and burnishing $42 \mathrm{CrMo} 4$ steel were carried out for the material state obtained after heat treatment to the 35 HRC hardness [2]. Material that is usually upgraded to such hardness is then milled in the process of making punches and die blocks for injection mould forms. Since in the process of burnishing plastic strains occur in a cuboidal workpiece, nonlinearities of milled workpiece material were taken into consideration. The characteristics of thermally improved material used in the physical model of the process were determined in tensile tests (Figure 2a) [2]. Other data from these tests, the changes of stress $\varepsilon$ as a function of relative elongation $\sigma$ were also recorded in the NastranNFX program. The physical model of the process also represented rolling of the burnishing ball moving perpendicularly to the cutter traces (Figure $2 b$ ).
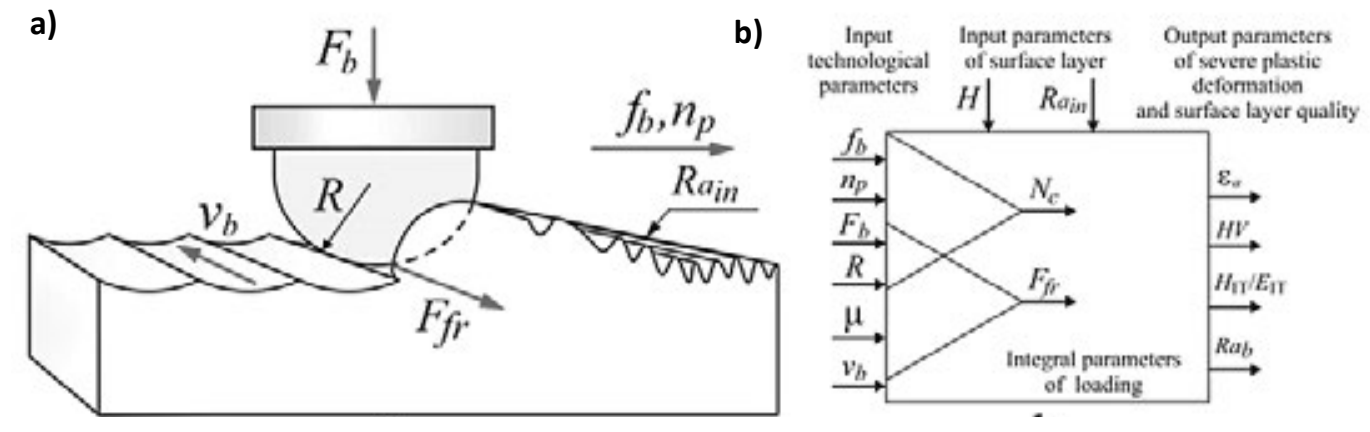

Fig. 1 Hybrid technology of surface finishing combining formed machining with finish burnishing a) kinematics of the burnishing process, b) technological parameters and effects Source: [12].

a)

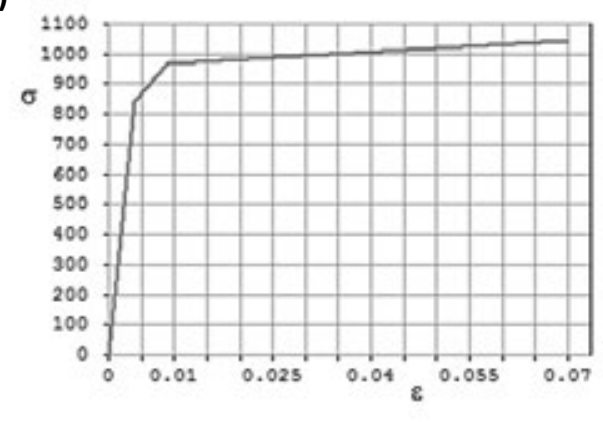

b)

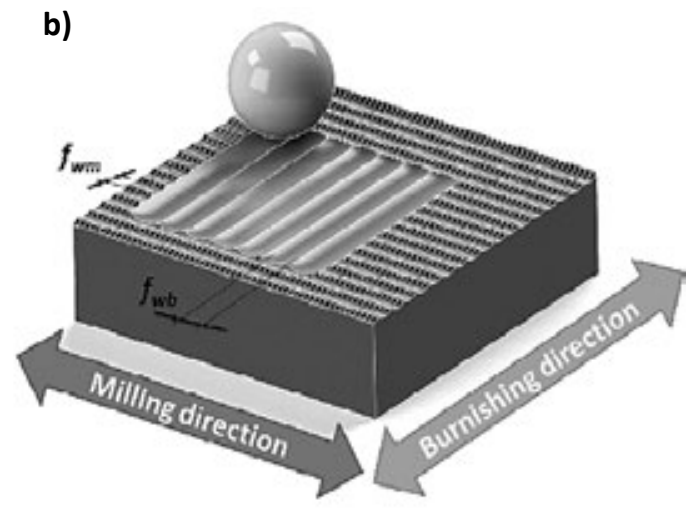

Fig. 2 Preparation of a physical model of milling and burnishing processes a) characteristics of $42 \mathrm{CrMo} 4$ steel after its hardening to the hardness $35 \mathrm{HRC}$, b) trajectory of burnishing ball movement on the milled surface, $f_{w m}$ - intervals between adjacent lace cutter passes (crossfeed), $f_{w b}$-distances between adjacent burnishing ball passes 
Young's modulus experimentally identified for $\mathrm{X} 42 \mathrm{Cr}$ Mo4 steel was $\mathrm{E}=210 \mathrm{GPa}$, and Poisson ratio of the material in the adopted model was $v=0.29$. The ceramic burnishing ball used in the tests, made of zirconium oxide $\mathrm{ZrO}_{2}-$ $80 \mathrm{HRC}$, had the same properties as the tested steel, Young's modulus $E=210 \mathrm{GPa}$, Poisson ratio $v=0.29$. An idealized state of SGS was adopted for the tests (neglecting meso- and nanoasperities), which only took into account the kinematic-geometrical conditions of the milling process, employing a torus cutter with round inserts with a diameter $d_{p}=10 \mathrm{~mm}$, with feed per cutting edge $f_{z}=0.1 \mathrm{~mm}$ and transverse intervals between passes of crossfeed sections $\mathrm{f}_{\mathrm{wm}}=0.5 \mathrm{~mm}$ (Figure 3).

Specimens in the physical model were cuboidal and had a width/height/length, respectively, $2 \times 1 \times 4.5 \mathrm{~mm}$.

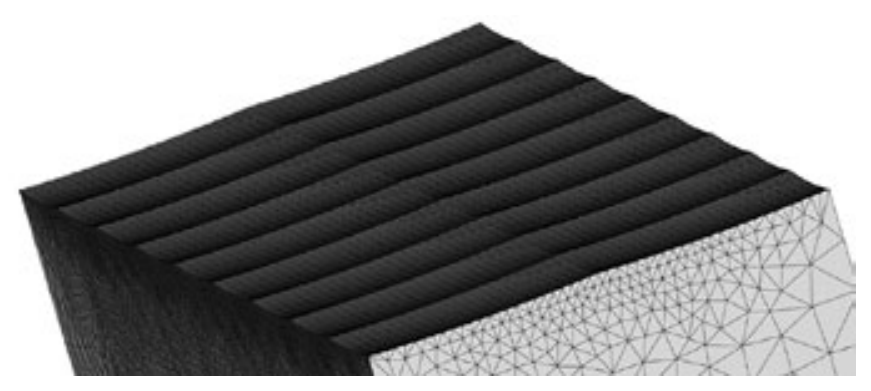

Fig. 3 A view of a computer model of a surface, taking into account kinematic-geometric conditions of milling with torus cutter (WNT R1000G.42.6.M16.IK) with six inserts with a diameter $d_{p}=10 \mathrm{~mm}$ (RD.X1003 MOT - WTN1205), $f_{z}=0.1 \mathrm{~mm}$ and $f_{w m}=0.5 \mathrm{~mm}$

\section{COMPUTER MODEL}

Because the process model geometry is symmetrical, the system burnishing ball-cuboidal workpiece was simplified as illustrated in Figure 4a. It is half of the physical model obtained from the simultaneous intersecting of the ball and workpiece by a plane passing through the ball centre and perpendicular to the shorter side of the workpiece base.
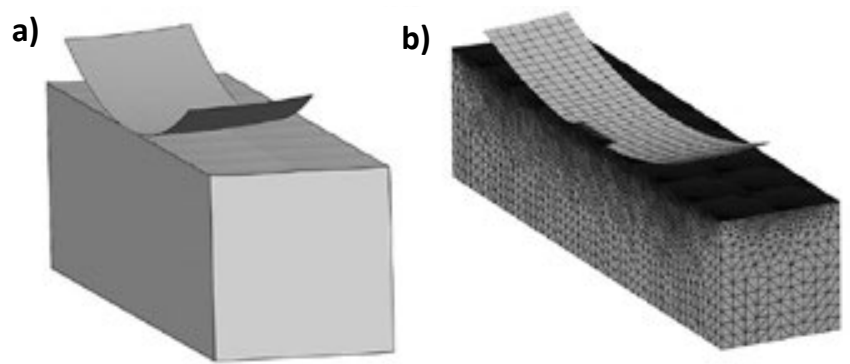

Fig. 4 Computer model of the process of burnishing a 42CrMo4 35 HRC steel workpiece by a ceramic burnishing ball

a) model view of the symmetry plane, b) nodes and finite elements of a selected sector

The spherical sector in the proximity of ball-workpiece surface area contact (Figure 4b) is modeled with 245 rigid flat elements and 288 nodes. The rectangular cuboid workpiece sector is modeled with 497516 3D tetramesh elements and 91086 nodes. The base of cuboidal milled workpiece was fixed and the nodes lying in the plane of model division could move. Three values of burnishing force $F_{b}$ were adopted in the tests: $250 \mathrm{~N}, 500 \mathrm{~N}$, and $1000 \mathrm{~N}$. Calculations were made by modeling the machining process in NastranNFX using a nonlinear statics module. Due to the occurrence of contact stresses (side of a finite element was $0.02 \mathrm{~mm}$, Figure 5), a densified division by finite elements was applied in the area surrounding the contact point between the ball and milled cuboidal workpiece surface.

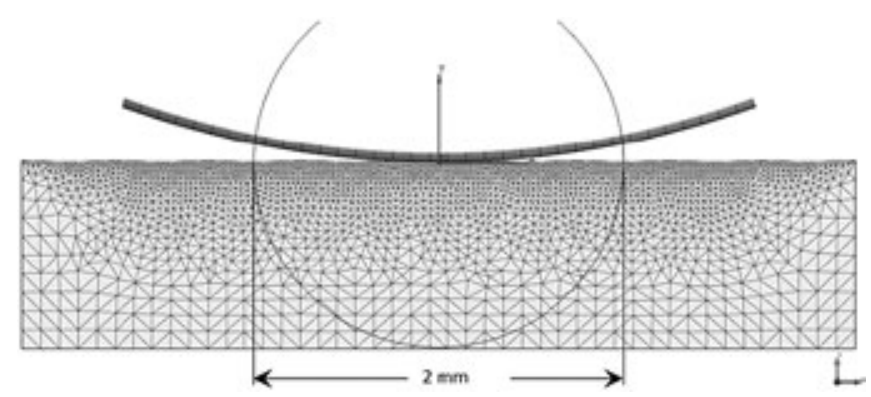

Fig. 5 A view of the ball-workpiece surface contact point - rolling modeled on a $2 \mathrm{~mm}$ section

\section{EXPERIMENTAL STUDIES}

The process modeling included the contact and pressing of the ball into the workpiece surface until a required burnishing force $F_{b}$ was attained, followed by ball rolling on a $2 \mathrm{~mm}$ section of the surface. Finally, the burnishing force was gradually reduced till the ball left the contact area. During the rolling, the ball rotated by a $23^{\circ}$ angle.

In a single numerical experiment the computing time was about 48 hours. The results comprised, among others, values of plastic deformations and associated stresses, analyzed further in this article. Example values of vertical displacements for a burnishing force $250 \mathrm{~N}$ are shown in Figure 6.

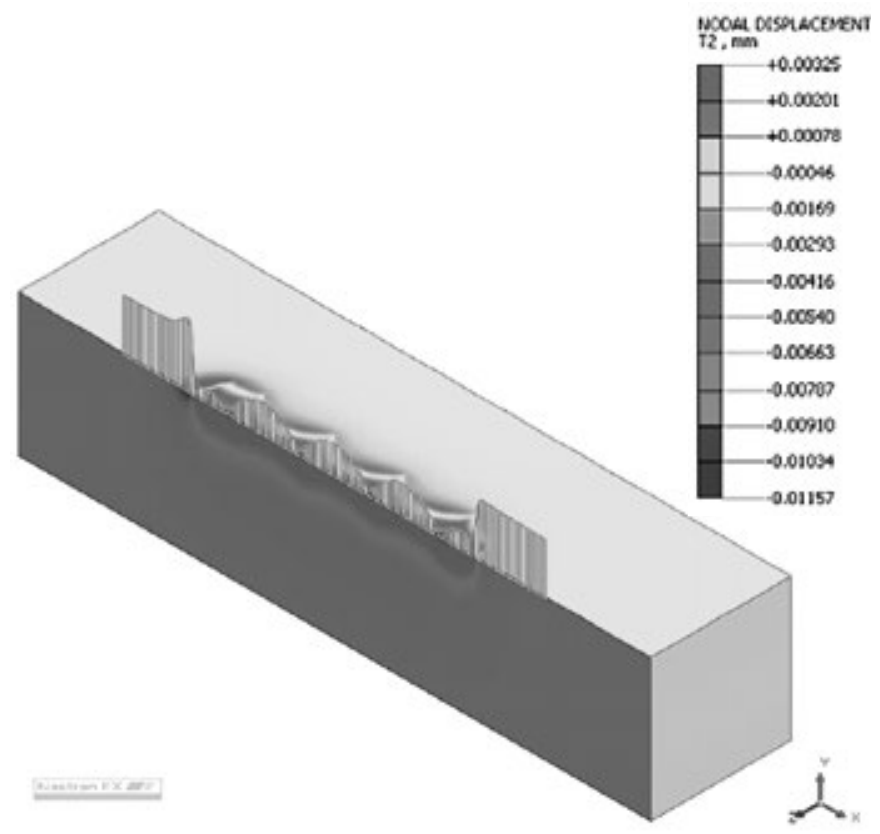

Fig. 6 A view of surface plastic deformations and residual stresses, obtained through simulation tests, burnishing force $F_{b}=250 \mathrm{~N}$

Figure 7 presents cumulative charts of plastic deformations of modeled surfaces after milling and burnishing with successive forces $F_{b} 250 \mathrm{~N}, 500 \mathrm{~N}$ and $1000 \mathrm{~N}$.

The final state of the profile surface after integrated milling and burnishing is a sum of the difference between peak heights and valley depths based on the model calculations made in NastranNFX. 


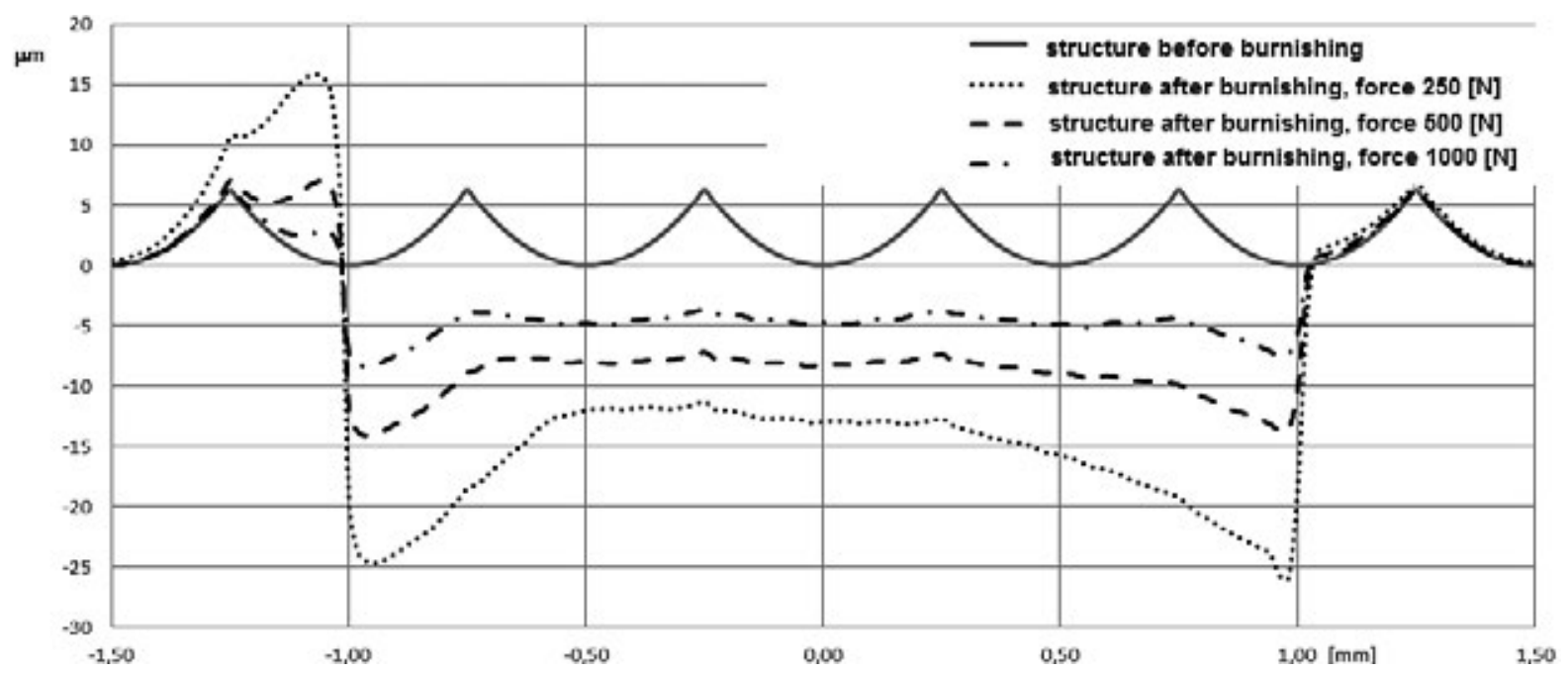

Fig. 7 The results of calculated vertical permanent displacements of the milled surface profile due to respective burnishing forces $F_{b}: 250 \mathrm{~N}, 500 \mathrm{~N}$ and $1000 \mathrm{~N}$ along the cuboid edge

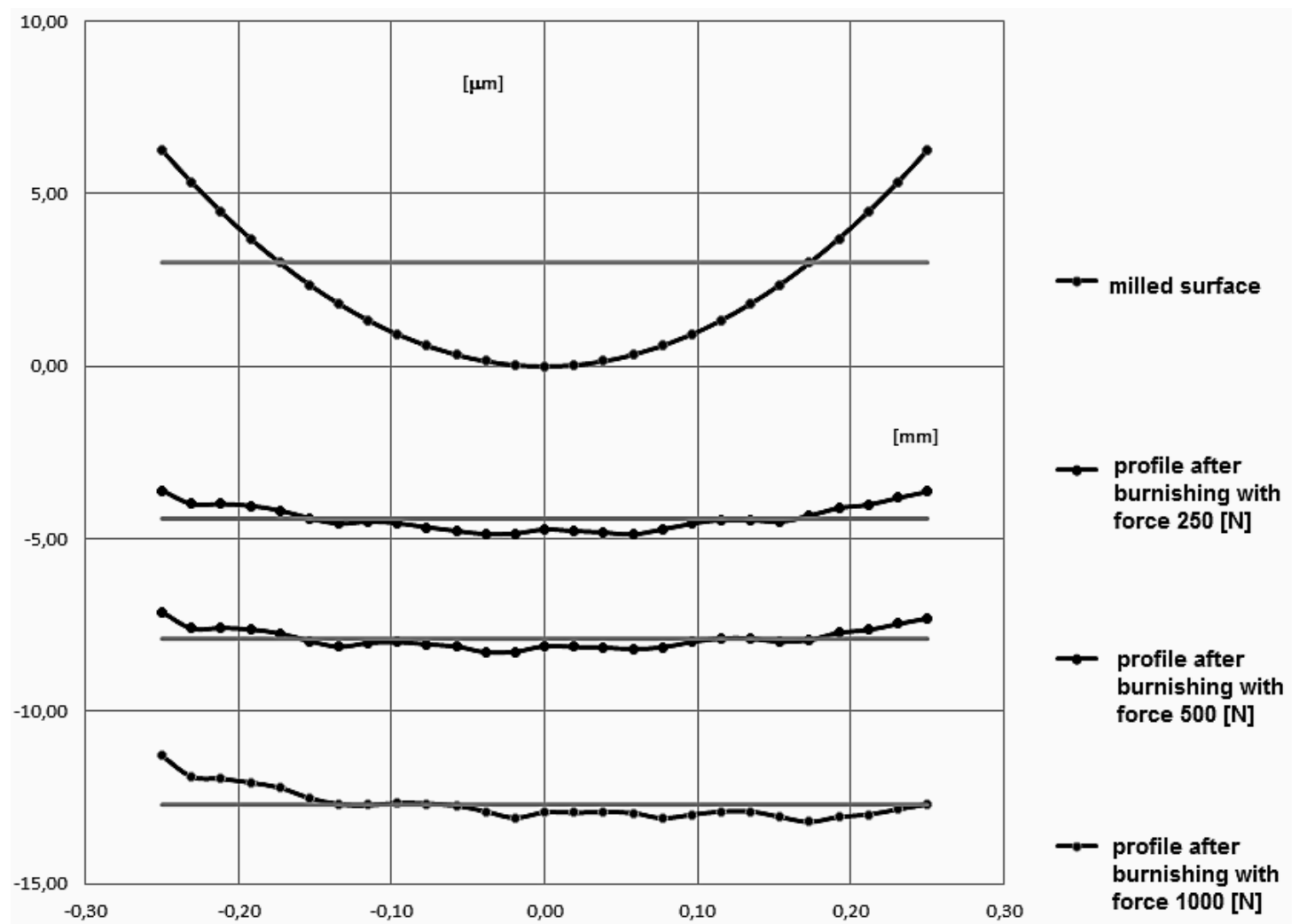

Fig. 8 Profiles of the milled and burnished surface from simulations where the burnishing force $F_{b}$ was, respectively, $250 \mathrm{~N}, 500 \mathrm{~N}, 1000 \mathrm{~N}$.

The roughness of an idealized milled surface in the physical model under consideration is understood as a mean deviation of the profile from the mean squared line. This roughness was determined in an elementary section between profile peaks spaced at intervals of cross feed passes, where the milling feed $f_{w m}=0.5 \mathrm{~mm}$ (Figure 8). 27 computational points were identified along that section. The elementary section division was determined by the size of model mesh at the ball-workpiece surface contact area.

Values of the parameter $R_{a}$ were determined from the obtained surface profiles similarly to the method used in SGS state survey by profilometers. In numerical tests the roughness of milled surface defined by parameter $R_{a}$ was
$1.91 \mu \mathrm{m}$ and is slightly higher than the $R_{a}$ value $1.56 \mu \mathrm{m}$ recorded after milling in the experimental test (Tab 1) [2].

The difference of parameter $R_{a}$ values is within an acceptable level of error. For the simplified kinematicgeometrical model, the difference of $R_{a}$ parameters in the milled surface description between the numerical and empirical experiments is $18.3 \%$ [2].

After burnishing with a force of $250 \mathrm{~N}$, roughness drops to $0.31 \mu \mathrm{m}$, a force of $500 \mathrm{~N}$ leads to still lower roughness of $0.24 \mu \mathrm{m}$. The highest burnishing force of $1000 \mathrm{~N}$ yields roughness of $0.32 \mu \mathrm{m}$, but this result is burdened with a large error due to a lack of symmetry in the deformed profile (Figure 7 - profile after $1000 \mathrm{~N}$ burnishing). 
Values of roughness parameters $R_{a}$ determined for four surface profiles after milling and burnishing with forces $F_{b}: 250 \mathrm{~N}, 500 \mathrm{~N}$ and $1000 \mathrm{~N}$

\begin{tabular}{|c|c|c|c|c|c|c|c|c|c|c|c|c|c|c|c|c|c|c|c|}
\hline \multicolumn{4}{|c|}{$Y \cdot$ profile height $[\mu \mathrm{m}]$} & \multicolumn{4}{|c|}{$\mathrm{Y}^{2} \cdot$ profile height squared $\left[\mu^{2}\right]$} & \multicolumn{4}{|c|}{$\begin{array}{l}\quad S=\sqrt{\frac{\sum Y^{2}}{27}} \\
\text { root mean squared }[\mu \mathrm{m}]\end{array}$} & \multicolumn{4}{|c|}{$\begin{array}{l}|Y-S| \\
\text { absolute deviation }[\mu \mathrm{m}]\end{array}$} & \multicolumn{4}{|c|}{$\begin{array}{l}R_{a}=\frac{\sum|Y-S|}{27} \\
\text { roughness } \mathbf{R}_{\mathrm{a}}[\mu \mathrm{m}]\end{array}$} \\
\hline \multirow[t]{2}{*}{ milling } & \multicolumn{3}{|c|}{ burnishing force $[\mathrm{N}]$} & \multirow[t]{2}{*}{ milling } & \multicolumn{3}{|c|}{ burnishing force $[\mathrm{N}]$} & \multirow[t]{2}{*}{ milling } & \multicolumn{3}{|c|}{ burnishing force $[\mathrm{N}]$} & \multirow[t]{2}{*}{ milling } & \multicolumn{3}{|c|}{ burnishing force $[\mathrm{N}]$} & \multirow[t]{2}{*}{ milling } & \multicolumn{3}{|c|}{ burnishing force $[\mathrm{N}]$} \\
\hline & 1000.0 & 500.0 & 250.0 & & 1000.0 & 500.0 & 250.0 & & 1000.0 & 500.0 & 250.0 & & 1000.0 & 500.0 & 250.0 & & 1000.0 & 500.0 & 250.0 \\
\hline 6.26 & -11.3 & -7.1 & -3.6 & 39.21 & 127.5 & 50.71 & 12.93 & & & & & 3.25 & 1.41 & 0.77 & 0.81 & & & & \\
\hline 5.34 & -11.9 & -7.6 & -4.0 & 28.47 & 141.5 & 57.74 & 15.91 & & & & & 2.32 & 0.81 & 0.30 & 0.42 & & & & \\
\hline 4.48 & -12.0 & -7.6 & -4.0 & 20.1 & 142.8 & 57.43 & 15.91 & & & & & 1.47 & 0.76 & 0.32 & 0.42 & & & & \\
\hline 3.71 & -12.1 & -7.6 & -4.0 & 13.73 & 145.5 & 58.14 & 16.32 & & & & & 0.69 & 0.64 & 0.27 & 0.37 & & & & \\
\hline 3.00 & -12.2 & -7.7 & -4.2 & 9.007 & 149.1 & 59.95 & 17.45 & & & & & 0.01 & 0.49 & 0.15 & 0.23 & & & & \\
\hline 2.37 & -12.5 & -8.0 & -4.4 & 5.623 & 156.6 & 63.34 & 19.36 & & & & & 0.64 & 0.19 & 0.06 & 0.01 & & & & \\
\hline 1.82 & -12.7 & -8.1 & -4.6 & 3.296 & 161.1 & 66.03 & 20.75 & & & & & 1.20 & 0.01 & 0.23 & 0.14 & & & & \\
\hline 1.33 & -12.7 & -8.0 & -4.5 & 1.779 & 161.8 & 64.3 & 20.25 & & & & & 1.68 & 0.01 & 0.12 & 0.09 & & & & \\
\hline 0.93 & -12.7 & -8.0 & -4.5 & 0.858 & 160.2 & 63.84 & 20.63 & & & & & 2.09 & 0.05 & 0.10 & 0.13 & & & & \\
\hline 0.59 & -12.7 & -8.1 & -4.7 & 0.351 & 160.8 & 64.88 & 21.74 & & & & & 2.42 & 0.03 & 0.16 & 0.25 & & & & \\
\hline 0.33 & -12.7 & -8.1 & -4.8 & 0.111 & 162.1 & 65.91 & 22.72 & & & & & 2.68 & 0.02 & 0.22 & 0.36 & & & & \\
\hline 0.15 & -12.7 & -8.3 & -4.9 & 0.022 & 166.5 & 68.64 & 23.65 & & & & & 2.86 & 0.20 & 0.39 & 0.45 & & & & \\
\hline 0.04 & -12.9 & -8.3 & -4.8 & 0.001 & 171.3 & 68.4 & 23.45 & & & & & 2.98 & 0.38 & 0.38 & 0.43 & & & & \\
\hline 0.00 & -13.1 & $-8,1$ & -4.7 & 0 & 167.1 & 65.76 & 22.33 & 3.013 & -12.71 & -7.895 & -4.411 & 3.01 & 0.22 & 0.21 & 0.31 & 1.91 & 0.32 & 0,24 & 0.31 \\
\hline 0.04 & -12.9 & -8.1 & -4.8 & 0.001 & 167.4 & 66.14 & 22.75 & & & & & 2.98 & 0.23 & 0.24 & 0.36 & & & & \\
\hline 0.15 & -12.9 & -8.1 & -4.8 & 0.022 & 166.9 & 66.37 & 23.16 & & & & & 2.86 & 0.21 & 0.25 & 0.40 & & & & \\
\hline 0.33 & -12.9 & -8.2 & -4.9 & 0.111 & 167.6 & 67.14 & 23.71 & & & & & 2.68 & 0.24 & 0.30 & 0.46 & & & & \\
\hline 0.59 & -12.9 & -8.1 & -4.7 & 0.351 & 171.5 & 66.32 & 22.31 & & & & & 2.42 & 0.39 & 0.25 & 0.31 & & & & \\
\hline 0.93 & -13.0 & -8.0 & -4.6 & 0.858 & 168.9 & 63.8 & 20.78 & & & & & 2.09 & 0.29 & 0.09 & 0.15 & & & & \\
\hline 1.33 & -12.9 & -7.9 & -4.4 & 1.779 & 166.5 & 62.16 & 19.78 & & & & & 1.68 & 0.20 & 0.01 & 0.04 & & & & \\
\hline 1.82 & -12.9 & -7.9 & -4.5 & 3.296 & 166.5 & 62.25 & 19.82 & & & & & 1.20 & 0.20 & 0.01 & 0.04 & & & & \\
\hline 2.37 & -13.1 & -8.0 & -4.5 & 5.623 & 170.6 & 63.68 & 20.25 & & & & & 0.64 & 0.36 & 0.08 & 0.09 & & & & \\
\hline 3.00 & -13.2 & -7.9 & -4.3 & 9.007 & 174.4 & 62.91 & 18.73 & & & & & 0.01 & 0.50 & 0.04 & 0.08 & & & & \\
\hline 3.71 & -13.1 & -7.7 & -4.1 & 13.73 & 170.5 & 59.59 & 16.86 & & & & & 0.69 & 0.35 & 0.18 & 0.31 & & & & \\
\hline 4.48 & -13.0 & -7.6 & -4.0 & 20.1 & 168.8 & 58.4 & 16.08 & & & & & 1.47 & 0.29 & 0.25 & 0.40 & & & & \\
\hline 5.34 & -12.8 & -7.5 & -3.8 & 28.47 & 164.8 & 55.73 & 14.54 & & & & & 2.32 & 0.13 & 0.43 & 0.60 & & & & \\
\hline 6.26 & -12.7 & -7.3 & -3.6 & 39.21 & 161.2 & 53.37 & 13.21 & & & & & 3.25 & 0.01 & 0.59 & 0.78 & & & & \\
\hline
\end{tabular}

\section{SUMMARY AND CONCLUSIONS}

The results of the numerical studies in reference to the outcome of empirical experiment lead to a number of conclusions.

In the numerical studies the authors adopted an idealized state of SGS after milling (excluding meso- and nanoroughness). The adopted simplification did not affect significantly the values of SGS height parameters. The differences in the values fall below $20 \%$ of the mean values recorded during the experimental tests. The adopted simplification in SGS modeling after milling permits to substantially accelerate the computing process.
Due to hardware and software limitations, in the preliminary studies only one burnishing pass was modeled, which led to a certain discrepancy between the results of plastic deformation of the surface in the numerical experiment and those in the empirical experiment. The source of the observed differences is the propagation of plastic deformation and stresses outside the zone of direct contact of the workpiece and burnishing tool. This practically means that subsequent burnishing ball passes take place on the surface already burnished.

The value of parameter $R_{a}$ visibly decreases for the modeled surface after milling and burnishing along with increasing force of burnishing. Our studies determined an opti- 
mal burnishing force $F_{b}$ having a value of $500 \mathrm{~N}$ (the lowest value of $R_{a}=0.24 \mu \mathrm{m}$ ); further increase of the burnishing force does not reduce the surface roughness values - which is consistent with the results obtained in the course of empirical experiment [2]. In further numerical studies the adopted range of burnishing force $F_{b}$ should be more densely divided, which will allow researchers to specify the optimum burnishing force $F_{b}$ (using methods of polyoptimization of complex regression equations derived from the results of simulation studies).

The developed numerical model of integrated technological process combining formed milling and finish burnishing in its present state is a tool offering wide possibilities for forecasting the state of the surface layer, in particular the form and values of hard-to-measure residual stresses.

The undertaken numerical studies will be continued. In the future the experimental model will be extended to examine the effects of burnishing the real surfaces after milling (dense mesh division 0.5-3 $\mu \mathrm{m}$ ) in a zone including a few, even more than ten mutually parallel burnishing passes, accounting for meso- and nanoroughness.

\section{REFERENCES}

[1] C.H. Chen and F.J. Shiou. "Determination of Optimal Ball-Burnishing Parameters for Plastic injection Moulding Steel", International Journal of Advanced Manufacturing Technology, vol. 21, issue 3, March 2003, pp. 177-185.

[2] D. Grochała, S. Berczyński and Z. Grządziel. "Stress in the surface layer of objects burnished after milling", International Journal of Advanced Manufacturing Technology, vol. 72, issue 9, June 2014, pp. 16551663.

[3] R. Gubała, D. Grochała and W. Olszak. „Mikrohydrauliczne narzędzie do nagniatania złożonych powierzchni przestrzennych", Mechanik, no. 1, 2014, pp. 22-23.

[4] J. Kalisz, K. Żak, W. Grzesik and K. Czechowski. „Characteristics of surface topography after rolling burnishing of EM AW-AICu4MgSi(A) aluminum alloy", Journal of Machine Engineering, vol. 15, no. 1, 2015, pp. 71-80.

[5] W. Kwaczyński, K. Chmielewski and D. Grochała. „Programowanie frezowania i nagniatania złożonych powierzchni przestrzennych na centrach frezarskich ze sterowaniem wieloosiowym", in Współczesne problemy technologii obróbki przez nagniatanie, vol. 3, W. Przybylski, Ed., Gdańsk: Politechnika Gdańska, Wydział Mechaniczny, 2011, pp. 179-191.

[6] L.N. López de Lacalle, A. Lamikiz, J. Muñoa and J.A. Sánchez. "Quality improvement of ball-end milled sculptured surfaces by ball burnishing", International Journal of Machine Tools \& Manufacture, vol. 45, issue 15, December 2005, pp. 1659-1668.

[7] L.N. López de Lacalle, A. Lamikiz, J.A. Sánchez and J.L. Arana. "The effect of ball burnishing on heat-treated steel and Inconel 718 milled surfaces", International Journal of Advanced Manufacturing Technology, vol. 32, issue 9-10, April 2007, pp. 958-968.

[8] A. Rodríguez, L.N. López de Lacalle, A. Celaya, A. Lamikiz and J. Albizuri. "Surface improvement of shafts by the deep ball-burnishing technique", Surface \& Coatings Technology, vol. 206, 2012, pp. 2817-2824.

[9] F.J. Shiou and C.H. Chen. "Ultra-precision surface finish of NAK80 mould tool steel using sequential ball burnishing and ball polishing processes", Journal of Materials Processing Technology, vol. 201, 2008, pp. 554-559.

[10] F.J. Shiou and C.H. Chuang. "Precision surface finish of the mold steel PDS5 using an innovative ball burnishing tool embedded with a load cell", Precision Engineering, vol. 34, issue 1 , January 2010, pp. 76-84.

[11] M. Sosnowski and D. Grochała. „Problemy technologii nagniatania powierzchni przestrzennych złożonych na centrach obróbkowych", Mechanik, no. 1, 2011, pp. 14-18.

[12] V.P. Kuznetsov, LYu. Smolin, A.J. Dmitrtev, S.Yu. Tarasov, V.G. Gorgots. "Toward control of subsurface strain accumulation in nanostructurin burnishin on hermostrenghened steel". Surface\&Coatings Technol. No. 285 2016, s. 171-178., http://dx.doi.org/10.1016/j.surfcoat.2015.11.045K.

[13] Żak and W. Grzesik. "Investigation of technological effects of ball burnishing after cryogenic turning of hard steel", Advances in Manufacturing Science and Technology, vol. 38, no. 1, 2014, pp. 37-52.

\author{
prof. dr hab. inż. Stefan Berczyński, dr inż. Daniel Grochała \\ West Pomeranian University of Technology \\ Faculty of Mechanical Engineering and Mechatronics \\ Aleja Piastów 19, 70-310 Szczecin, POLAND \\ e-mails: stefan.berczynski@zut.edu.pl \\ daniel.grochala@zut.edu.pl \\ dr inż. Zenon Grządziel \\ Maritime University of Szczecin \\ Faculty of Marine Engineering \\ ul. Wały Chrobrego 1-2, 70-500 Szczecin, POLAND \\ e-mail: z.grzadziel@am.szczecin.pl
}

The article in Polish language version available on the web-

site of the journal
Artykuł w polskiej wersji językowej dostępny na stronie internetowej czasopisma. 